\title{
THE DEVELOPMENT, EVALUATION, AND ANTIOXIDANT ACTIVITY ANALYSIS OF CHITOSAN MICROCAPSULES CONTAINING RED GINGER OLEORESIN WITH SODIUM TRIPOLYPHOSPHATE PREPARED BY EMULSION CROSS-LINKING TECHNIQUE
}

\author{
Jayanudin $^{1,2}$, Mohammad Fahrurrozi ${ }^{1}$, Sang Kompiang Wirawan ${ }^{1}$, Rochmadi ${ }^{1, \otimes}$
}

https://doi.org/10.23939/chcht15.01.040

\begin{abstract}
In this study, chitosan-based carrier of red ginger oleoresin was prepared using the emulsion crosslinking technique with sodium tripolyphosphate (TPP) as a cross-linking agent. The effect of chitosan and TPP concentration, as well as $\mathrm{pH}$ on the encapsulation efficiency, particle size and characterization of chitosan microcapsule was determined. The antioxidant activity of microcapsules was analyzed. Chitosan microcapsules containing red ginger oleoresin were produced although with non-smooth surfaces.
\end{abstract}

Keywords: antioxidant activity, red ginger oleoresin, chitosan microcapsule, emulsion cross-linking, sodium tripolyphosphate.

\section{Introduction}

Modern drug delivery systems use polymers as carriers of drugs to control the drug release. The advantages of the controlled release include increased efficacy, reduced toxicity, and improved patient compliance and comfort [1]. Chitosan is a biocompatible, biodegradable and non-toxic biopolymer. The high nature of chitosan bioadhesive properties has more advantages compared to other natural polymers such as cellulose, xanthan gum and starch [2]. This nature has made chitosan as a very suitable drug carrier. Chitosan microcapsules are a form of drug delivery system that can be prepared by physical methods such as spray drying, extrusion, fluidized bed, and others. In additon to the physical methods, there are chemical methods which include coacervation, in situ polymerization, emulsion

\footnotetext{
${ }^{1}$ Chemical Engineering Department, Faculty of Engineering,

Universitas Gadjah Mada

Jl. Grafika No. 2, Yogyakarta, Indonesia

${ }^{2}$ Chemical Engineering Department, Faculty of Engineering, Universitas Sultan Ageng Tirtayasa

Jl. Jenderal Sudirman km.3, Cilegon, Indonesia

rochmadi@ugm.ac.id

(C) Jayanudin, Fahrurrozi M., Wirawan S., Rochmadi, 2021
}

cross-linking, and interfacial polymerization. The method used in this study was an emulsion cross-linking with sodium tripolyphosphate as a cross-linking agent. Emulsion cross-linking method was developed using glutaraldehyde or glutaraldehyde saturated toluene (GST) as a cross-linking agent. The microcapsules produced by this method have good spherical geometry with a smooth surface and have been successfully carried out by some authors [3-5]. These studies used glutaraldehyde which might have side effects if used for drug delivery. Although Campos et al. [6] concluded that there are no adverse effects on cell viability due to cross-reactions which caused toxicity levels to be minimal, a safe cross-linking agent to replace glutaraldehyde is also necessary.

Sodium tripolyphosphate (TPP) is the most widely used cross-linking agent because it is non-toxic and multivalent to prevent possible damage to drugs [7]. TPP may be used by two different ways. First, TPP is added dropwise to a mixture of polymers and bioactive substances. This way has been reported by Jarudilokkul et al. [8] to encapsulate protein and by Alqahtani et al. [9] to prepare diclofenac-containing chitosan nanoparticles. The second way is the mixture of polymers and bioactive substances is added dropwise to the TPP solution as practiced in the research conducted by Csaba et al. [10] for the delivery of oligonucleotide and plasmid DNA and encapsulation of curcumin loaded in chitosan as a drug delivery carrier as reported in [7]. Ionic gelation/ ionotropic gelation methods using TPP as a cross-linking agent produce microspheres/nanospheres chitosan, where the bioactive is more dispersed over the carrier material. The matrix type of encapsulate has a disadvantage as there is a possibility of an active agent found on the particle surface, so it is not effective for the active agent that issensitive to environmental influences. This method is not suitable for encapsulation of red ginger oleoresins which are sensitive to changes in heat, oxygen, and microorganisms. The emulsion cross-linking technique makes the red ginger oleoresin coated in a chitosan 
solution because the first step is to form an oil-in-water emulsion (red ginger oleoresin coated by chitosan solution) and then the emulsion is added to the vegetable oil to form an oil-in-water-in-oil emulsion. The use of vegetable oils aims to stabilize the emulsion even without using an emulsifier. The final product is microcapsules where the red ginger oleoresin is inside the core which is protected by chitosan as a wall material of microcapsules (red ginger oleoresin encapsulated by chitosan).

Red ginger oleoresin contains many active components which are useful for antioxidant, antimicrobial, and anti-inflammatory [11], but has weaknesses that are sensitive to heat, light, and oxygen [12]. Other disadvantages are poor solubility, and low bioavailability. The chitosan-based red ginger oleoresin delivery carrier can improve stability, solubility and bioavailability. In this study, chitosan containing the red ginger oleoresin as a carrier was prepared by the emulsion cross-linking method with sodium tripolyphosphate (TPP) as a crosslinking agent. One of the the aims of this study was to determine the effect of chitosan concentration, $\mathrm{pH}$, and concentration of TPP solution on encapsulation efficiency, particle size, characterization of microcapsules and release profile of red ginger oleoresin. Another aim was to conduct an analysis of the antioxidant activity of red ginger oleoresin microcapsules.

\section{Experimental}

\subsection{Materials}

Red ginger oleoresin was obtained from Lansida group Ltd. Sodium tripolyphosphate was gained from Sigma-Aldrich. These materials were then used as crosslinking agents. Glacial acetic acid was purchased from Merck, and toluene technical grade was provided byTri Jaya Dinamika Ltd. Other materials such as petroleum ether, $n$-hexane, and methanol were supplied by Labora Ltd. Chitosan with $87.2 \%$ degree of deacetylation (DD) was provided by Biotech Surindo Ltd., and corn oil was produced by Surya Agung Ltd.

\subsection{Preparation of Chitosan Microcapsules Containing Red Ginger Oleoresin}

Emulsion cross-linking technique used to prepare red ginger oleoresin containing chitosan microsphere was a modification from works [13] and [8]. Chitosan was dissolved with $1 \%(\mathrm{v} / \mathrm{v})$ glacial acetic acid to generate $1 \%$, $2 \%, 3 \%$, and $4 \%(\mathrm{w} / \mathrm{v})$ chitosan concentration. $4 \mathrm{~g}$ of red ginger oleoresin were added to $40 \mathrm{ml}$ of chitosan solution, and then stirred using IKA-Werk Ultra-Turrax for $30 \mathrm{~min}$ to prepare an oil-in-water $(\mathrm{O} / \mathrm{W})$ emulsion. The first emulsion was added to corn oil and stirred again for $1 \mathrm{~h}$ to get oil-in-water-in-oil (O/W/O) emulsion. Sodium tripolyphosphate (TPP) solution was added dropwise to the emulsion. After TPP was added, the $\mathrm{pH}$ of the mixture was adjusted to 5 by adding $2 \%$ acetic acid and the mixture was still stirred for $3 \mathrm{~h}$. Red ginger oleoresin loaded in chitosan microcapsules was separated with a centrifuge and then washed using petroleum ether followed by hexane. The final stage was the drying of chitosan microcapsules in an oven at $348 \mathrm{~K}$.

\subsection{Encapsulation Efficiency}

Encapsulation efficiency was determined based on the method reported in [3] and [14]. Surface oil was determined by adding $1 \mathrm{~g}$ of dried microcapsules into hexane and stirring for $1 \mathrm{~min}$. Then it was filtered, dried, and weighed. Total oil was determined by extracting $1 \mathrm{~g}$ of microcapsules in $200 \mathrm{ml}$ of methanol for $6 \mathrm{~h}$ in a Soxhlet extractor. After completion, the microcapsules were dried and weighed. The encapsulation efficiency was calculated using Eqs. (1)-(3).

$$
\begin{gathered}
\text { Surface oil }\left(S_{O}\right)=w_{i}-w_{f} \\
\text { Total oil }\left(T_{O}\right)=w_{i}-w_{\text {extr }} \\
\% \text { Encapsulation efficiency }(E E)=\frac{T_{O}-S_{O}}{T_{O}} \cdot 100
\end{gathered}
$$

where $w_{i}, w_{f}$ and $w_{\text {extr }}$ are the microcapsules initial weight, final weight and weight after extracted in a Soxhlet, respectively, $\mathrm{g}$.

\subsection{Methods of Analysis}

\subsubsection{Scanning electron microscopy (SEM)}

Morphological analysis of red ginger oleoresin containing chitosan microcapsules was conducted using a scanning electron microscope (SEM) of JSM 6510LA type. Resolution: high vacuum mode $3.0 \mathrm{~nm}(30 \mathrm{kV})$ and low vacuum mode $4.0 \mathrm{~nm}(30 \mathrm{kV})$; acceleration voltage is 0.5 $30 \mathrm{kV}$. Chitosan microcapsules were coated with platinum.

\subsubsection{Thermal gravimetric analysis (TGA)}

Thermal gravimetric analysis (TGA) with DTG-60 Shimadzu type was used to analyze the thermal stability using DTG-60 detector. The samples were heated from 303 to $573 \mathrm{~K}$ with a rate of $10 \mathrm{~K} / \mathrm{min}$; nitrogen flow rate was $30 \mathrm{ml} / \mathrm{min}$.

\subsubsection{Fourier-transform infrared spectroscopy (FTIR)}

Interaction analysis between components in microcapsules was carried out via Fourier transform infrared spectroscopy (FTIR) using $\mathrm{KBr}$ pellets in a Shimadzu IR spectrophotometer, which operated between 500 and $4000 \mathrm{~cm}^{-1}$. 


\subsubsection{Analysis of particle size}

The diameter of microcapsules was determined by a digital microscope with $500 \times$ magnification referring to the study reported by Jayanudin et al. [15]. Microcapsule size calibration was done by comparing the real diameter size of the wire fibers with the size of wire fibers using a digital microscope, and then made as a correction factor. The diameter size of microcapsules measured by a digital microscope was multiplied by a correction factor to obtain the real diameter size of microcapsules. The average diameter was calculated by observing 100 microcapsules. The average diameter of microcapsule was determined in accordance with Eq. (4):

$$
\bar{d}=\sum_{i=n}^{n} \frac{d_{i}}{N}
$$

where $\bar{d}$ is an average diameter, $\mathrm{m} ; d_{i}$ is a droplet diameter, $\mathrm{m}$; and $N$ is the total number of calculated droplets.

\subsubsection{Analysis of antioxidant activity}

Antioxidant activity of red ginger oleoresins in chitosan microspheres could be determined using DPPH assay. This method was modified from the works [16] and [17]. The reaction mixture consisted of the sample $(1 \mathrm{ml})$, ethanol $(6 \mathrm{ml})$ and $0.5 \mathrm{mM}$ DPPH solution in ethanol $(0.6 \mathrm{ml})$. After $30 \mathrm{~min}$ a reaction between DPPH and the antioxidant compound occurred causing a color change which was recorded by GENESYS 10S UV/VIS spectrophotometer with a wavelength of $517 \mathrm{~nm}$ was used. Determination of blank absorbance was determined by the ethanol mixture with samples. The percentage of antioxidant activity was calculated by Eq. (5):

$$
A A \%=100-\left[\frac{\left(A b s_{\text {control }}-A b s_{\text {sample }}\right) \cdot 100}{A b s_{\text {control }}}\right]
$$

where $A b s_{\text {control }}$ is the control reaction of absorbance (only absorbance of DPPH) and $A b s_{\text {tsample }}$ is an absorbance in the presence of a sample (absorbance of DPPH along with concentrations of sample).

\section{Results and Discussion}

\subsection{Encapsulation Efficiency}

Encapsulation efficiency determines the effectiveness of the encapsulation process of red ginger oleoresin using the emulsion cross-linking with TPP as a cross-linking agent. Table 1 shows the effect of chitosan solution concentration, TPP solution concentration and $\mathrm{pH}$ on the encapsulation efficiency of red ginger oleoresin microcapsules. The value of the encapsulation efficiency was found to be from $83.25 \pm 0.04$ to $91.64 \pm 0.02 \%$. Minimum encapsulation efficiency was generated at $4 \%$ chitosan concentration and $\mathrm{pH} 4$. While, the maximum value of encapsulation efficiency was obtained at $4 \%$ chitosan concentration, and $\mathrm{pH} 5$.

At low $\mathrm{pH}$, the most amino group and TPP molecules are protonated. The result is a lower charging density of the molecule. The chitosan molecules cannot be adequately cross-linked by TPP to form stable particles [18] and this causes lower encapsulation efficiency at $\mathrm{pH}$ 4 than that at $\mathrm{pH}$ 5. Meanwhile the encapsulation efficiency decreases again at $\mathrm{pH} 6$ because this value of $\mathrm{pH}$ approaches the isoelectric point of chitosan $(\mathrm{pKa}=$ $=6.3$ ). So, the deprotonation process could occur and cause aggregation by decreasing the repulsion force between particles [19]. The aggregation process between particles allows a small portion of red ginger oleoresin to be diffused out during the process of chitosan microcapsules compaction. Similar results were reported by Patil et al. [20], when increasing $\mathrm{pH}$ caused a decrease in encapsulation efficiency.

In this study the encapsulation efficiency has higher values (from $87.81 \pm 0.03$ to $91.64 \pm 0.02 \%$ ) in comparison with those using ionic gelation methods $(45.77 \pm 1.25 \%$ [21], $31.1 \pm 3.1 \%$ [9], and $54.72 \pm 1.342 \%$ [22]).

Table 1

\begin{tabular}{|c|c|c|c|c|}
\hline \multicolumn{5}{|c|}{ Parameter } \\
\hline Chitosan concentration, $\%(\mathrm{w} / \mathrm{v})$ & TPP concentration, $\%(\mathrm{w} / \mathrm{v})$ & $\mathrm{pH}$ & ${ }^{a, b} E E, \%$ & ${ }^{a, c}$ Particle size, $\mu \mathrm{m}$ \\
\hline 1 & \multirow{4}{*}{5} & \multirow{4}{*}{5} & $87.81 \pm 0.03$ & $35.71 \pm 6.6$ \\
\hline 2 & & & $89.40 \pm 0.07$ & $36.95 \pm 5.4$ \\
\hline 3 & & & $90.18 \pm 0.05$ & $38.52 \pm 4.9$ \\
\hline 4 & & & $91.64 \pm 0.02$ & $41.43 \pm 8.3$ \\
\hline \multirow{3}{*}{4} & \multirow{3}{*}{5} & 4 & $83.25 \pm 0.04$ & $47.35 \pm 9.1$ \\
\hline & & 5 & $91.64 \pm 0.02$ & $41.43 \pm 8.3$ \\
\hline & & 6 & $91.42 \pm 0.01$ & $48.11 \pm 9.1$ \\
\hline
\end{tabular}

Encapsulation efficiency and particle size of chitosan microcapsules filled
with red ginger oleoresin depending on chitosan and TPP concentrations and pH

Notes: ${ }^{a}$ Mean $\pm \mathrm{SD},{ }^{b} n=3,{ }^{c} n=100$ 


\subsection{Particle Size}

The particle size was determined by observing a hundred particles using a digital microscope before the average diameter was defined. The effect of the parameters on the average particle size can be seen in Table 1. The average particle size was found to be from $35.71 \pm 6.6$ to $63.95 \pm 7.5 \mu \mathrm{m}$. The particle size of chitosan microcapsules containing red ginger oleoresin increased with the increase in chitosan concentration. The lower viscosity of the chitosan solution had a better solubility for the efficiency of the gelation process that caused the particle size to become smaller. The lower concentration of chitosan solution results in the smaller particle size and vice versa. The lower molecular weight of chitosan could reduce particle size because it has a shorter polymer chain that supports dissolution and interaction with TPP [23]. Higher concentrations of chitosan solution make the walls of the microcapsules more rigid and compact [24], the walls become thicker, so the diameter of the microcapsules becomes larger.

Particle size was also influenced by $\mathrm{pH}$. Table 1 showed that larger particle size was obtained at $\mathrm{pH} 4$ than that at $\mathrm{pH} 5$, but the increase of the $\mathrm{pH}$ value to 6 again increases the particle size, even greater than those at $\mathrm{pH} 4$ and 5. This increase is caused by the reduction in crosslinking due to the predominance of deprotonation. The decrease in $\mathrm{pH}$ causes quite strong charge interaction between two molecules, thus the sizes of microcapsules become larger [18].

The chitosan concentration and $\mathrm{pH}$ are the important parameters to determine the particle size of chitosan microcapsules. The highest average particle size in this study is $48.11 \pm 9.1 \mu \mathrm{m}$ obtained at $4 \%(\mathrm{w} / \mathrm{v})$ concentration of chitosan solution and $\mathrm{pH}$ 6. Meanwhile, the smallest particle size is $35.71 \pm 6.6 \mu \mathrm{m}$ which was obtained at $1 \%(\mathrm{w} / \mathrm{v})$ concentration of chitosan solution and $\mathrm{pH} 5$. If we compare the particle size obtained using the ionic gelation method (from $22.45 \pm 0.90$ to $1287.70 \pm 0.60 \mathrm{~nm}$ [21] and from $295.33 \pm 3.01$ to $336 \pm 22.1 \mathrm{~nm}$ [9]), the particle size in this study is larger.

\subsection{Characterization of Red Ginger Oleoresin Containing Chitosan Microcapsules}

\subsubsection{FTIR analysis}

FTIR analysis for chitosan and chitosan-TPP microcapsules is shown in Fig. 1. FTIR analysis shows that the absorption bands for chitosan and chitosan-TPP microcapsules are at 3425.58 and $3387 \mathrm{~cm}^{-1}$, assigned to $\mathrm{N}-\mathrm{H}$ and $\mathrm{O}-\mathrm{H}$ stretching vibrations, respectively.
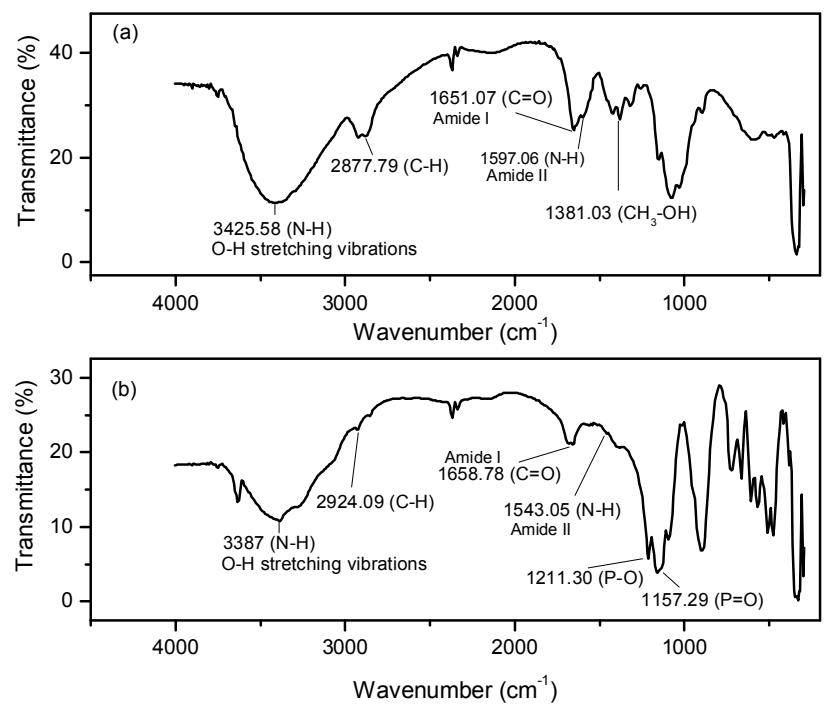

Fig. 1. FTIR spectra of chitosan (a) and chitosan/TPP (b). Chitosan microcapsules used in FTIR analysis was without red ginger oleoresin

Fig. 1 shows that there are differences in the peak between chitosan (a) and chitosan-TPP microcapsules (b). The differences are the peak of $1211.30 \mathrm{~cm}^{-1}(\mathrm{P}-\mathrm{O})$ and $1157.29 \mathrm{~cm}^{-1}(\mathrm{P}=\mathrm{O})$

\subsubsection{TGA and DTA analyses}

Thermogravimetric analysis (TGA) is a type of test carried out to determine a weight loss in a sample due to temperature changes. TGA is used to characterize materials such as polymers for determining the degradation of temperature, decomposition of organic and inorganic materials, and solvent residues. TGA analysis is usually simultaneous with DTA analysis, which is used to analyze material changes as a temperature function. DTA is used to study thermal properties and phase changes due to enthalpy changes from the material. Fig. 2 shows the results of TGA/DTA analysis for chitosan microcapsules containing red ginger oleoresins based on changes in chitosan concentration.

TGA analysis was carried out within the temperature range of $303-573 \mathrm{~K}$. The weight loss occurred in two stages. The first stage took place within $303-385 \mathrm{~K}$ and the second stage $385-573 \mathrm{~K}$. The weight loss in the first stage occurred due to evaporation of water in chitosan microcapsules. After that, chitosan microsphere melted and decomposed at $385-573 \mathrm{~K}$. At this stage, the weight of chitosan microsphere decreased drastically because of decomposition. The acetylated and deacetylated units of the polymer could activate depolymerization and decomposition. The saccharide rings could also dehydrate at the temperatures of 463-603 K [25]. The weight losses were $24.158,18.168,19.564$ and $28.273 \%$ (Fig. 2). 
The results of DTA analysis are also shown in Fig. 2. It can be seen that chitosan microcapsules have different endothermic peaks at different concentrations. The melting point (endothermic peak) for $1 \%(\mathrm{w} / \mathrm{v})$ concentration of chitosan solution occurred at $401.34 \mathrm{~K}$ with enthalpy $\Delta H=-126.49 \mathrm{~J} / \mathrm{g}$; for $2 \%(\mathrm{w} / \mathrm{v})$ concentration - at $396.73 \mathrm{~K}$ with $\Delta H=-105.26 \mathrm{~J} / \mathrm{g}$; for $3 \%(\mathrm{w} / \mathrm{v})$ concentration - at $397.30 \mathrm{~K}$ with $\Delta H=-129.15 \mathrm{~J} / \mathrm{g}$; and

\author{
for $4 \%(\mathrm{w} / \mathrm{v})$ concentration - at $396.49 \mathrm{~K}$ with \\ $\Delta H=-239.63 \mathrm{~J} / \mathrm{g}$.
}

\subsubsection{SEM analysis}

The SEM analysis was used to determine the surface morphology and shape of chitosan microcapsules. Fig. 3 shows the surface morphology of chitosan microcapsules cross-linked with TPP at various magnifications.
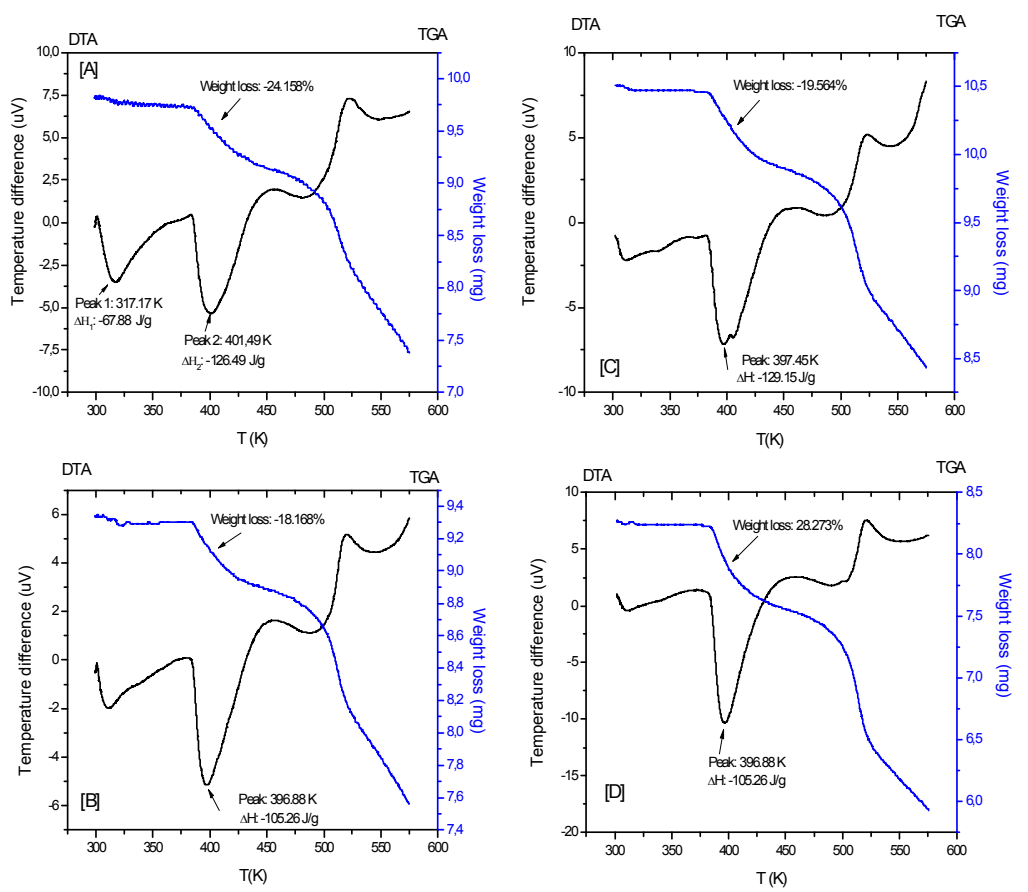

Fig. 2. TGA and DTA analyses of chitosan microcapsules for different concentrations (w/v) of chitosan solution: $1 \%$ (a), $2 \%$ (b), $3 \%$ (c), and $4 \%$ (d). The chitosan microcapsules containing red ginger oleoresin were obtained at $5 \%$ TPP concentration and $\mathrm{pH} 5$.
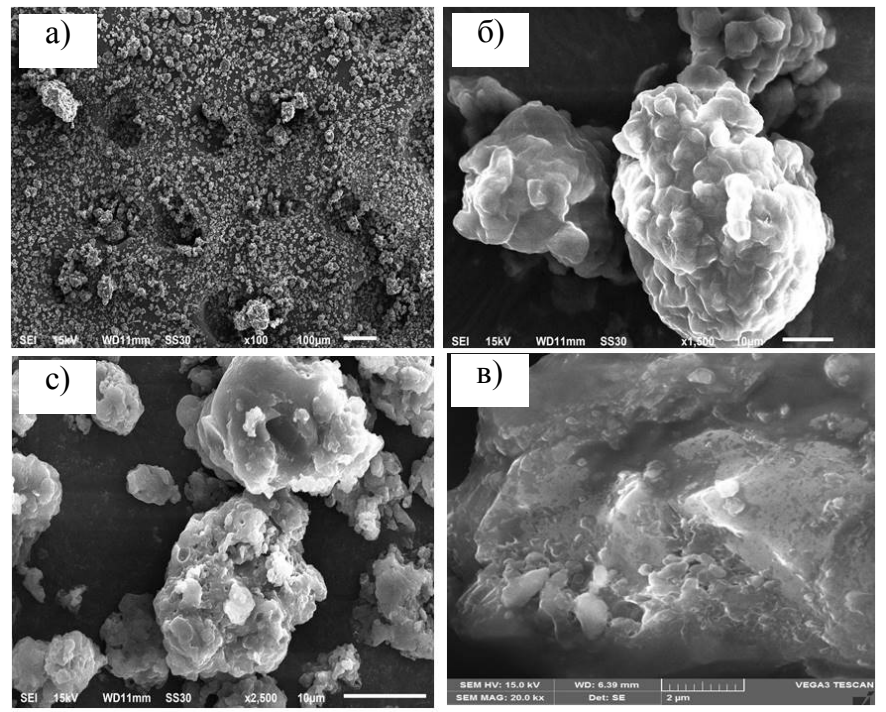

Fig. 3. Surface morphology analysis of chitosan microcapsules containing red ginger oleoresin with magnification of $100 \times(a) ; 1,500 \times(b) ; 2,500 \times(c)$ and 20,000× (d). This form of microcapsules was made at $4 \%(\mathrm{w} / \mathrm{v})$ concentration of chitosan solution, $5 \%(\mathrm{w} / \mathrm{v})$ concentration of TPP solution, and $\mathrm{pH} 5$ 
Fig. 3 shows that the surface shape of chitosan microcapsules cross-linked with TPP generates a nonsmooth surface and does not exhibit good spherical geometry. Many chitosan flakes are attached to the microcapsules surface. At the initial process of solidification, the microcapsule wall layer is a gel-shaped one because it was cross-linked with TPP. Then, it was dissolved due to the addition of acetic acid to adjust the $\mathrm{pH}$. The chitosan solution was hardened again during the cross-linking process. This phenomenon was very likely caused by the number of chitosan flakes attached to the surface of the microcapsules, as shown in Figs. $3 \mathrm{c}$ and d. The uneven surface shape did not exhibit good spherical geometry and might be caused by non-uniform crosslinking reaction of chitosan-TPP as shown in Fig. $3 \mathrm{~b}$. Meanwhile, the solid surface is seen with $20,000 \times$ magnification (Fig. 3d), even though many flakes of chitosan are attached to the chitosan microcapsule surface.

\subsubsection{Antioxidant activity of red ginger oleoresin containing chitosan microsphere}

DPPH (1,1-diphenyl-2-picrylhydrazyl) assay was used to analyse the antioxidant activity of chitosan microcapsules containing red ginger oleoresin. This method was used to predict antioxidant activity by the mechanisms in which antioxidants in a substance inhibit lipid oxidation by a DPPH scavenging radical. DPPH can be a stable diamagnetic molecule because it can accept electrons or hydrogen radicals. It can be oxidized with difficulty and then irreversibly [26]. The results of the antioxidant activity of red ginger oleoresin containing chitosan microsphere can be seen in Table 2.

Table 2

Antioxidant activity of red ginger oleoresin microcapsules

\begin{tabular}{|c|c|}
\hline Chitosan concentration, $\%$ (w/v) & Antioxidant activity, $\%$ \\
\hline 1 & $58.65 \pm 1.54$ \\
\hline 2 & $67.48 \pm 1.43$ \\
\hline 3 & $64.22 \pm 1.29$ \\
\hline 4 & $83.63 \pm 1.52$ \\
\hline $\mathrm{pH}$ & \\
\hline 4 & $54.59 \pm 1.49$ \\
\hline 5 & $83.63 \pm 1.52$ \\
\hline 6 & $77.01 \pm 1.16$ \\
\hline
\end{tabular}

Notes: Mean $\pm \mathrm{SD}, n=3$

In general, the antioxidant activity increases with the increase in the concentration of chitosan. Although the solution with $2 \%(\mathrm{w} / \mathrm{v})$ chitosan concentration has higher antioxidant activity than that with $3 \%(\mathrm{w} / \mathrm{v})$ concentration of chitosan, the difference is not significant. Antioxidant activity at $\mathrm{pH} 6$ is lower than that at $\mathrm{pH} 5$ and higher than at
$\mathrm{pH}$ 4. This is likely related to the encapsulation efficiency produced, as shown in Table 1. The higher encapsulation efficiency has higher oleoresin content, so the antioxidant activity is also higher. The value of antioxidant activity produced from chitosan microcapsules containing red ginger oleoresins is quite high (from $54.59 \pm 1.49$ to $83.63 \pm 1.52 \%$. When compared to the results reported by Eleazu et al. [27] who represented antioxidant activity from 45 to $75 \%$, the antioxidant activity values obtained in this study are higher. They are even higher than those for the synthetic antioxidants. As reported in [17], the antioxidant activity of butylatedhydroxyanisole (BHT) and butylatedhydroxytoluene (BHA) is $48-60 \%$ and $50-69 \%$, respectively. The obtained values are also higher than the antioxidant activity for ginger oleoresin resulting from ginger extraction $(40-76 \%)$ [28]. The same is for the antioxidant activity of oleoresin which was calculated using 2,2'-azino-bis (3-ethylbenzenthiazoline-6-sulphonic) acid (ABS) method (from $9.17 \pm 0.94 \%$ to $50.58 \pm 2.86 \%$ ) [29]. The high value of the antioxidant activity of red ginger oleoresin containing chitosan microcapsules shows one of the success parameters of the encapsulation process by emulsion cross-linking technique using sodium tripolyphosphate as a cross-linking agent.

\section{Conclusions}

In summary, this study reveals that the concentration of chitosan, TPP concentration, and $\mathrm{pH}$ have an impact on the efficiency, particle size, thermal stability, and antioxidant activity. Based on the parameters studied, chitosan microspheres obtained at $4 \%$ chitosan concentration, 5\% TPP concentration, and $\mathrm{pH} 5$ show the highest encapsulation efficiency and antioxidant activity: $91.64 \pm 0.02 \%$ and $83.63 \pm 1.52 \%$, respectively. The particle size was from $35.71 \pm 6.6$ to $63.95 \pm 7.5 \mu \mathrm{m}$. Although the surface was not smooth, chitosan microspheres have been successfully produced. The values of antioxidant activity of red ginger oleoresin microcapsules were from $54.59 \pm 1.49$ to $83.63 \pm 1.52 \%$.

\section{Acknowledgments}

We would like to express our gratitude to the Ministry of Research, Technology and Higher Education (Kemenristekdikti) of the Republic of Indonesia which has financially supported this research. Our thanks also go to the Chemical Engineering Department, Universitas Gadjah Mada for all research facilities that have been provided.

\section{References}

[1] Abu-Thabit N., Makhlouf A.: Historical Development of Drug Delivery Systems: From Conventional Macroscale to Controlled, 
Targeted, and Responsive Nanoscale Systems. [in:] Makhlouf A., Abu-Thabit N. (Eds.), Stimuli Responsive Polymeric Nanocarriers for Drug Delivery Applications, Woodhead Publishing 2018, 1-41. https://doi.org/10.1016/B978-0-08-101997-9.00001-1

[2] Kotze A., Luessen H., Thanou M. et al:: Chitosan and Chitosan Derivatives as Absorption Enhancers for Peptide Drugs Across Mucosal Epithelia [in:] Mathiowitz E., Chickering III D., Lehr C. (Eds.), Bioadhesive Drug Delivery Systems: Fundamentals, Novel Approaches, and Development. CRC Press 2019, 341-386.

[3] Jayanudin, Fahrurrozi M., Wirawan S., Rochmadi: J. Appl. Biomater. Funct. Mater., 2019, 17, 1.

https://doi.org/10.1177/2280800018809917

[4] Jameela S., Jayakrishnan A.: Biomaterials, 1995, 16, 769. https://doi.org/10.1016/0142-9612(95)99639-4

[5] Ofokansi K., Kenechukwu F., Isah A., Okigbo E: Trop. J. Pharm. Res., 2013, 12, 19. https://doi.org/10.4314/tjpr.v12i1.4 [6] Campos E., Coimbra P., Gil M: Polym. Bull., 2013, 70, 549. https://doi.org/10.1007/s00289-012-0853-4

[7] Akolade J., Oloyede H., Salawu M et al.: J. Drug Deliv. Sci. Technol., 2018, 45, 11. https://doi.org/10.1016/j.jddst.2018.02.001 [8] Jarudilokkul S., Tongthammachat A., Boonamnuayvittaya V.: Korean J. Chem. Eng., 2011, 28, 1247. https://doi.org/10.1007/s11814-010-0485-z

[9] Alqahtani F., Aleanizy F., El Tahir E. et al:: Saudi Pharm. J., 2019, 27, 82. https://doi.org/10.1016/j.jsps.2018.08.001

[10] Csaba N., Köping-höggård M., Alonso M.: Int. J. Pharm., 2009, 382, 205. https://doi.org/10.1016/j.ijpharm.2009.07.028

[11] El-Ghorab A., Nauman M., Anjum F. et al.: J. Agric. Food Chem., 2010, 58, 8231. https://doi.org/10.1021/jf101202x

[12] Vaidya S., Bhosale R., Singhal R.: Dry. Technol., 2006, 24, 983. https://doi.org/10.1080/07373930600776159

[13] Jayanudin, Fahrurrozi M., Wirawan S., Rochmadi: Res. J. Pharm. Technol., 2018, 11, 3431. https://doi.org/10.5958/0974360X.2018.00633.9

[14] Tan L., Chan L., Heng P.: J. Microencapsul., 2005, 22, 253. https://doi.org/10.1080/02652040500100329

[15] Jayanudin, Fahrurrozi M., Wirawan S., Rochmadi: Eng. Sci. Technol. Int. J., 2018, 22, 458.

https://doi.org/10.1016/j.jestch.2018.11.008

[16] Jayanudin, Fahrurrozi M., Wirawan S., Rochmadi: Sustain.

Chem. Pharm., 2019, 12, 100132.

https://doi.org/10.1016/j.scp.2019.100132

[17] Gbadegesin M., Odunola O.: Br. J. Med. Med. Res., 2013, 3,

2141. https://doi.org/10.9734/BJMMR/2013/4356

[18] Liu H., Gao C.: Polym. Adv. Technol., 2009, $20,613$.

https://doi.org/10.1002/pat.1306
[19] Esquivel R., Juárez J., Almada M. et al.: Int. J. Polym. Sci., 2015, 2015. https://doi.org/10.1155/2015/502058

[20] Patil S., Gupta V., Gupta K., Doddayya H.: J. Biomed. Pharm. Res., 2014, 3, 51.

[21] Hasheminejad N., Khodaiyan F., Safari M.: Food Chem., 2019, 275, 113. https://doi.org/10.1016/j.foodchem.2018.09.085

22] Tripathy S., Das S., Prasad S. et al.: Int. J. Pharm., 2012, 434, 292. https://doi.org/10.1016/j.ijpharm.2012.05.064

[23] Omar Zaki S., Ibrahim M., Katas H.: J. Nanotechnol., 2015, 2015. https://doi.org/10.1155/2015/919658

[24] Ganesh S., Kumar D., Kumar B. et al.: Asian J. Pharm. Clin. Res., 2010, 3, 179.

[25] Hosseini S., Zandi M., Rezaei M., Farahmandghavi F.: Carbohydr. Polym., 2013, 95, 50.

https://doi.org/10.1016/j.carbpol.2013.02.031

[26] Kedare S., Singh R.: J. Food Sci. Technol., 2011, 48, 412. https://doi.org/10.1007/s13197-011-0251-1

[27] Eleazu C., Amadi C., Iwo G. et al.: Clin. Toxicol., 2013, 3, 1. [28] Murthy P., Gautam R., Pura Naik J.: J. Food Process. Preserv., 2015, 39, 1905. https://doi.org/10.1111/jfpp.12428

[29] Bellik Y.:Asian Pacific J. Trop. Dis., 2014, 4, 40. https://doi.org/10.1016/S2222-1808(14)60311-X

Received: March 21, 2019 / Revised: April 26, 2019 / Accepted: August 30, 2019

\section{ОДЕРЖАННЯ, ХАРАКТЕРИСТИКА ТА АНТИОКСИДАЦІЙНА АКТИВНІСТЬ ХІТОЗАНОВИХ МІКРОКАПСУЛ 3 ЖИВИЦЕЮ ЧЕРВОНОГО ІМБІРЮ ТА ТРИПОЛІФОСФАТОМ НАТРІЮ, ПРИГОТОВЛЕНИХ МЕТОДОМ ЕМУЛЬСІЙНОГО ЗШИВАННЯ}

\begin{abstract}
Анотація. 3 використанням методу емульсійного зиивання приготовлено хітозанові капсули живиці червоного імбирю з триполіфосфатом натрію (ТПН) як зииваючого агента. Визначено вплив концентрації хітозану та ТПН, а також величини рН на ефективність інкапсуляиії, розмір частинок та властивості мікрокапсул хітозану. Визначено антиоксидантну активність мікрокапсул. Показано, щчо мікрокапсули можуть бути успішно одержані, не зважаючи на негладку поверхню.
\end{abstract}

Ключові слова: антиоксидаційна активність, живиия червоного імбиру, мікрокапсула хітозану, емульсійне зиивання, триполіфосфат натрію. 